\title{
The hyperaccumulator Sedum plumbizincicola harbors metal-resistant endophytic bacteria that improve its phytoextraction capacity in multi-metal contaminated soil
}

Ying Ma, Rui S. Oliveira, Fengjiao Nai, Mani Rajkumar, Yongming Luo, Inês Rocha, Helena Freitas

\section{Abstract}

Endophyte-assisted phytoremediation has recently been suggested as a successful approach for ecological restoration of metal contaminated soils, however little information is available on the influence of endophytic bacteria on the phytoextraction capacity of metal hyperaccumulating plants in multi-metal polluted soils. The aims of our study were to isolate and characterize metalresistant and 1-aminocyclopropane-1-carboxylate (ACC) utilizing endophytic bacteria from tissues of the newly discovered $\mathrm{Zn} / \mathrm{Cd}$ hyperaccumulator Sedum plumbizincicola and to examine if these endophytic bacterial strains could improve the efficiency of phytoextraction of multi-metal contaminated soils. Among a collection of 42 metal resistant bacterial strains isolated from the tissues of $S$. plumbizincicola grown on $\mathrm{Pb} / \mathrm{Zn}$ mine tailings, five plant growth promoting endophytic bacterial strains (PGPE) were selected due to their ability to promote plant growth and to utilize ACC as the sole nitrogen source. The five isolates were identified as Bacillus pumilus E2S2, Bacillus sp. E1S2, Bacillus sp. E4S1,Achromobacter sp. E4L5 and Stenotrophomonas sp. E1L and subsequent testing revealed that they all exhibited traits associated with plant growth promotion, such as production of indole-3-acetic acid and siderophores and solubilization of phosphorus. These five strains showed high resistance to heavy metals $(\mathrm{Cd}, \mathrm{Zn}$ and $\mathrm{Pb}$ ) and various antibiotics. Further, inoculation of these ACC utilizing strains significantly increased the concentrations of water extractable $\mathrm{Cd}$ and $\mathrm{Zn}$ in soil. Moreover, a pot experiment was conducted to elucidate the effects of inoculating metal-resistant ACC utilizing strains on the growth of $\mathrm{S}$. plumbizincicola and its uptake of $\mathrm{Cd}, \mathrm{Zn}$ and $\mathrm{Pb}$ in multi-metal contaminated soils. Out of the five strains, B. pumilus E2S2 significantly increased root (146\%) and shoot (17\%) length, fresh (37\%) and dry biomass (32\%) ofS. plumbizincicola as well as plant Cd uptake (43\%), whereas Bacillus sp. E1S2 significantly enhanced the accumulation of $\mathrm{Zn}(18 \%)$ in plants compared with non-inoculated controls. The inoculated strains also showed high levels of colonization in rhizosphere and plant tissues. Results demonstrate the potential to improve phytoextraction of soils contaminated with multiple heavy metals by 
inoculating metal hyperaccumulating plants with their own selected functional endophytic bacterial strains.

\section{Keywords}

Endophytic bacteria; Heavy metals; Hyperaccumulator; Phytoextraction; Sedum plumbizincicola

\section{Introduction}

Hyperaccumulator plants have great potential for phytoextraction of heavy metal contaminated soils (Reeves and Baker, 2000), and several plant species (e.g., Alyssum bertolonii, Arabidopsis halleri, Solanum nigrum, Eichhornia crassipes, and Thlaspi caerulescens) have been proposed for phytoextraction of $\mathrm{Ni}, \mathrm{Cd}, \mathrm{Zn}$ and $\mathrm{Pb}$ (McGrath et al., 2006). The process of phytoextraction is often more time consuming than other physiochemical technologies, and it is usually limited by the low biomass and slow growth of most hyperaccumulators. To enhance the phytoextraction efficiency, functional rhizobacteria have been used in several successful studies of treatment of heavy metal contaminated soils (Ma et al., 2009, Ma et al., 2013 and Rajkumar et al., 2013). More recently, attention has concentrated on the bioaugmentation with metal resistant and plant growth promoting endophytic bacteria (PGPE) for enhancing phytoextraction efficiency (Ma et al., 2011b). In some cases, PGPE can promote plant growth and establishment under adverse conditions through various mechanisms including production of plant beneficial substances such as 1-aminocyclopropane-1carboxylate (ACC) deaminase, indole-3-acetic acid (IAA), siderophores, and/or solubilization of mineral nutrients ( Ma et al., 2011a). Moreover, certain PGPE could potentially reduce the phytotoxic effects, alter heavy metal availability to the plant by producing siderophores, organic acids, biosurfactants and extracellular polymeric substances (Rajkumar et al., 2009).

Sedum plumbizincicola is a newly discovered $\mathrm{Zn} / \mathrm{Cd}$ hyperaccumulator from lead-zinc mining areas in Zhejiang Province, PR China (Wu et al., 2008). S. plumbizincicola is capable of extracting high concentrations of $\mathrm{Zn}$ and $\mathrm{Cd}$ from polluted soils, and may have great potential for phytoextraction of metal contaminated soils (Ma et al., 2013). Although the heavy metal accumulation and phytoextraction efficiency of $S$. plumbizincicola have been studied, the effects of metal-resistant and ACC utilizing endophytic bacteria on accumulation of heavy metals and nutrients in S. plumbizincicolagrown in metal contaminated soils and PGPE-metal-hyperaccumulator interactions have not received much attention. 
In this study, a novel phytoextraction system comprising hyperaccumulator plants and their endophytic bacteria was constructed for the remediation of soil contaminated with multiple metals. The objectives of our study were: i) to isolate and characterize metal-resistant and ACC utilizing endophytic bacteria from tissues of $S$. plumbizincicola and ii) to examine if the target PGPE could improve the efficiency of phytoextraction by investigating several parameters, such as plant growth, nutrients accumulation, metal mobilization and uptake by S. plumbizincicola in multi-metal contaminated soils. To our knowledge, this is the first report to use functional endophytic bacteria withS. plumbizincicola for improving phytoextraction of soils polluted with multiple metals.

\section{Materials and methods}

\subsection{Isolation of metal resistant PGPE}

The endophytic bacterial strains were isolated from fresh fine tissues (stems and leaves) of $S$. plumbizincicola grown in the vicinity of $\mathrm{Pb} / \mathrm{Zn}$ mine tailings in Chunan city of Zhejiang province, China, following the method of Ma et al. (2011b). The soil where the plants were growing has the following characteristics: soil $\mathrm{pH}(1: 1 \mathrm{w} / \mathrm{v}$ water) and organic matter were 7.6 and $1.36 \%$, respectively, and total metal concentrations were $1826.7 \mathrm{mg} \mathrm{Cu} \mathrm{kg}^{-1}, 991.9 \mathrm{mg} \mathrm{Zn} \mathrm{kg}^{-1}$; $91.3 \mathrm{mg} \mathrm{Cd} \mathrm{kg}^{-1}$ and $14.2 \mathrm{~g} \mathrm{~Pb} \mathrm{~kg}^{-1}$. Diluted tissue extracts $(100 \mu \mathrm{L})$ were plated onto sucrose minimal salts low-phosphate (SLP) agar plates amended with $100 \mathrm{mg}$ of $\mathrm{Cd}\left(\mathrm{CdCl}_{2}\right), \mathrm{Zn}\left(\mathrm{ZnSO}_{4}\right)$, or $\mathrm{Pb}\left[\mathrm{Pb}\left(\mathrm{NO}_{3}\right)_{2}\right]$ per liter. After incubating at $37^{\circ} \mathrm{C}$ for $5 \mathrm{~d}$, morphologically distinct bacterial colonies were randomly picked, purified and restreaked on the same media until the colonies of each isolate were apparently morphologically homogeneous (Ma et al., 2009). In order to isolate PGPE, all the metal-resistant isolates were tested whether they were able to grow on DF salts minimal medium (Dworkin and Foster, 1958) with ACC as the sole nitrogen $(\mathrm{N})$ source. Further, the plant growth promoting effects of the isolated endophytic bacterial strains were determined by assessing the relative elongation ratio (RER) of root and shoot, plant fresh and dry weight, and vigor index, of the model plant Brassica napuswith or without the presence of $\mathrm{Cd}(6 \mu \mathrm{M} \mathrm{CdCl})$ according to the modified assay of Ma et al. (2009).

\subsection{Characteristics of PGPE}

\subsubsection{Genetic identification}

Genomic DNA was isolated from pure bacterial colonies by using the QuickExtract $^{\mathrm{TM}}$ bacterial DNA extraction kit. Primers FAM27f (5'GAGTTTGATCMTGGCTCAG-3') (Lane, 1991) and 1492r (5'- 
GGYTACCTTGTTACGACTT-3') (Kane et al., 1993), a pair of highly conserved flanking sequences were used to amplify the $16 \mathrm{~S}$ ribosomal genes under the reaction conditions described by Branco et al. (2005). PCR products were visualized on $1.5 \%$ agarose gels, and the products were excised and purified from salts and primers using the PCR purification kit (Roche Diagnostics) according to the manufacturer's instructions prior to sequencing. Partial nucleotide sequence of the amplified 16S rDNA was determined using an $A B I$ 3130XL automatic DNA sequencer (Applied Biosystems, Perkin Elmer), and then compared to similar sequences in the GenBank using the BLASTn analysis (Altschul et al., 1997).

\subsubsection{Sensitivity to metals and antibiotics}

The minimal inhibitory concentrations of heavy metals $(\mathrm{Cd}, \mathrm{Zn}$ and $\mathrm{Pb})$ at varying concentrations (50-6000 $\left.\mathrm{mg} \mathrm{L}^{-1}\right)$ against isolates were determined on LuriaBertani (LB) medium as the lowest concentration of metal ion preventing bacterial growth (Yilmaz, 2003). The antibiotic sensitivity of bacterial isolates was determined by the disc diffusion method (Rajkumar et al., 2008). A $0.1 \mathrm{~mL}$ of undiluted overnight grown bacterial culture [ $10^{8}$ colony-forming units (CFU) $\left.\mathrm{mL}^{-1}\right]$ was spread on LB agar plates in order to form a bacterial lawn. After incubating for $24 \mathrm{~h}$ at $27^{\circ} \mathrm{C}$, antibiotic discs were placed on the surface of the bacterial lawn and plates were incubated at $27{ }^{\circ} \mathrm{C}$. The following antibiotics were used: ampicillin $(10 \mu \mathrm{g})$, chloramphenicol $(30 \mu \mathrm{g})$, kanamycin $(30 \mu \mathrm{g})$, penicillin $(20 \mu \mathrm{g})$, streptomycin $(20 \mu \mathrm{g})$ and tetracycline $(30 \mu \mathrm{g})$. Three replicate plates with six discs each were used for each strain-antibiotic combination. The diameter of the inhibition zone was measured after $24 \mathrm{~h}$ and bacterial strains were classified as resistant $(R)(<10 \mathrm{~mm})$, intermediate (I) $(10-15 \mathrm{~mm})$ and susceptible (S) $(>15 \mathrm{~mm})$.

\subsubsection{Plant beneficial features}

The ACC deaminase activity of cell extracts was assayed based on the determination of $\alpha$-ketobutyrate $(\alpha-K B)$ generated through the enzymatic cleavage of ACC according to Honma and Shimomura (1978). To measure the specific activity of the cultures, protein content was determined by the Lowry method (Lowry et al., 1951).

Bacterial IAA production ability was colorimetrically measured by mixing $4 \mathrm{~mL}$ of Salkowski's reagent (Gordon and Weber, 1951) with $1 \mathrm{~mL}$ of supernatant obtained from bacterial culture grown in LB medium with L-tryptophan (500 $\mu \mathrm{g} \mathrm{mL}^{-1}$ ) (Bric et al., 1991). The absorbance of pink color developed after 
25 min incubation was read at $O D_{530 \mathrm{~m}}$. The concentration of IAA in each sample was determined using a calibration curve of IAA ranging from 0.5 to $25 \mu \mathrm{g} \mathrm{mL}^{-1}$. The bacterial cultures were grown at $27{ }^{\circ} \mathrm{C}$ for $120 \mathrm{~h}$ at $175 \mathrm{rpm}$ in modified Pikovskaya's medium (Sundara-Rao and Sinha, 1963) supplemented with $0.5 \%$ tricalcium phosphate (TCP). The culture supernatants were collected by centrifugation at $8000 \mathrm{rpm}$ for $20 \mathrm{~min}$. The soluble phosphate in the culture supernatant was quantified according to Fiske and Subbarow (1925).

The production of siderophore was qualitatively assessed in chrome azurol $\mathrm{S}$ (CAS) agar medium according to Schwyn and Neilands (1987). CAS agar plates were spot inoculated with bacterial cultures $(10 \mu \mathrm{L}$ of approximately $10^{8} \mathrm{CFU} \mathrm{mL-1}$ ) and incubated at $27^{\circ} \mathrm{C}$ for $5 \mathrm{~d}$. The diameters of orange halo formed around colonies indicated the siderophore production level. The production of catechol and hydroxamate siderophores in culture supernatants of bacteria grown under iron-limiting conditions in casamino acids medium was also quantitatively determined following the method of Arnow (1937) and Atkin et al. (1970), respectively.

\subsection{Effects of PGPE on mobility of soil metals}

Soils used in the assay were obtained from metal contaminated agricultural land in Fuyang city of Zhejiang province, PR China. Five soil samples were randomly collected (0-15 cm depth) and mixed in a composite sample (Table 1). The soil was air dried, crushed to pass through a 2-mm sieve and then autoclaved at $121^{\circ} \mathrm{C}$ for $2 \mathrm{~h}$. Pure culture of bacterial strain was incubated at $27^{\circ} \mathrm{C}$ with $200 \mathrm{rpm}$ shaking for $24 \mathrm{~h}$. After adjusting cells to an $\mathrm{OD}_{600}$ of 1.5 (cuvette path length of $1 \mathrm{~cm}$ ), $5 \mathrm{~mL}$ of cultures were centrifuged, then gently washed twice with $0.05 \mathrm{M}$ phosphate buffer $(\mathrm{pH}$ 7.2) and three times with sterile deionized water, recentrifuged and finally resuspended in $5 \mathrm{~mL}$ sterile deionized water. One $\mathrm{mL}$ of washed bacterial culture was added to $1 \mathrm{~g}$ of sterilized soil in $50-\mathrm{mL}$ sealed polypropylene centrifuge tubes. Sterile deionized water was used as the control inoculum. Tubes were weighed and kept at $27^{\circ} \mathrm{C}$ with $200 \mathrm{rpm}$ in the dark. The tubes were again weighed after $7 \mathrm{~d}$ and sterile deionized water was added to compensate for water-evaporation. Ten milliliters of sterile deionized water were added to each tube to extract the soil water-soluble metal (Ma et al., 2009). The soil suspensions were centrifuged $(7000 \mathrm{rpm}$ for $10 \mathrm{~min}$ ) and filtered. A flame atomic absorption spectrophotometer (AAS) (PerkinElmer model 100, Massachusetts, USA) was used to determine the concentrations of $\mathrm{Cd}, \mathrm{Zn}$ and $\mathrm{Pb}$ in the filtrate (Freitas et al., 2004 and $\mathrm{Ma}$ et al., 2010). In addition, the pH of the medium was also recorded with a pH meter (P260; Beckman) equipped with glass electrode. 
Table 1

Physicochemical properties of soils used in the metal mobilization and pot experiments.

\begin{tabular}{|c|c|c|c|c|c|c|c|c|c|}
\hline \multirow[t]{3}{*}{ Soil property } & \multirow[t]{3}{*}{$\mathrm{pH}$} & \multirow{3}{*}{$\begin{array}{l}\text { CEC } \\
\overline{\mathrm{cmol} \mathrm{kg}^{-1}}\end{array}$} & \multirow{3}{*}{$\begin{array}{l}\mathrm{OM} \\
\overline{\mathrm{g} \mathrm{kg}^{-1}}\end{array}$} & \multicolumn{6}{|c|}{ Total element concentration } \\
\hline & & & & $\mathrm{N}$ & $P$ & $\mathrm{~K}$ & $\mathrm{Cd}$ & $\mathrm{Zn}$ & $\mathrm{Pb}$ \\
\hline & & & & $\overline{\mathrm{g} \mathrm{kg}^{-1}}$ & $\mathrm{~g} \mathrm{~kg}^{-1}$ & $\mathrm{~g} \mathrm{~kg}^{-1}$ & $\overline{\mathrm{mg} \mathrm{kg}{ }^{-1}}$ & $\mathrm{mg} \mathrm{kg}{ }^{-1}$ & $\mathrm{mg} \mathrm{kg}{ }^{-1}$ \\
\hline & $8.1 \pm 0.3$ & $11.4 \pm 0.1$ & $36.3 \pm 1.2$ & $1.7 \pm 0.0$ & $1.1 \pm 0.1$ & $18.6 \pm 0.2$ & $5.9 \pm 0.3$ & $736.2 \pm 13.1$ & $153.3 \pm 8.2$ \\
\hline
\end{tabular}

Values are means \pm standard deviations of five replicates. CEC, cation exchange capacity; OM, organic matter.

\subsection{Extracellular enzyme production}

Pectinase and cellulase activities of bacterial strain were determined using the disc plate method of Mateos et al. (1992). The bacterial cultures were individually plated on nitrogen-freebase (NFB) agar medium supplemented with $0.5 \%$ pectin and carboxymethyl cellulose as the sole carbon source. The pectinase and cellulase activities were determined with bromothymol blue and congo red, respectively for measuring the size of clear zone formed around the colony.

\subsection{Pot experiment}

Experiments for determining the effects of the endophytic bacterial strains on plant growth and uptake of metals and nutrients were carried out in pots containing non-sterilized metal contaminated soil (Table 1). The soil was air-dried and passed through a $2 \mathrm{~mm}$ sieve. The seedlings of $S$. plumbizincicola were obtained from an old $\mathrm{Pb} / \mathrm{Zn}$ mine in Chunan city of Zhejiang province, PR China. Fresh shoot samples were clipped with shears approximately $5 \mathrm{~cm}$ long with 1 pair of leaves and $4-5$ nodes, cleaned with tap water and grown in a half-strength Hoagland's nutrient solution for 7 days. Roots of precultured seedlings were surface-sterilized by sequential immersion in $70 \%(\mathrm{v} / \mathrm{v})$ ethanol for $1 \mathrm{~min}$, and $3 \%$ $\mathrm{NaClO}$ for 3 min and washed several times with sterile deionized water.

To determine the ability of endophytic bacteria to colonize and survive in plant hosts, mutants of the endophytic bacterial strains marked with antibiotic resistance were obtained after plating of the parental strains onto LB agar amended with chloramphenicol (150 $\mathrm{mg} \mathrm{L}^{-1}$ ) (Ma et al., 2011b). After incubation for $5 \mathrm{~d}$ at $28^{\circ} \mathrm{C}$, the chloramphenicol resistant strains were selected based on similarities with the parent strains in colony morphology, metal resistance, metal solubilizing abilities and plant growth promotion and were recultured on chloramphenicol free medium to check stability of the antibiotic resistance marker.

For inoculation of the seedlings, the endophytic bacterial strains marked with antibiotic resistance were grown overnight in LB medium at $27^{\circ} \mathrm{C}$. Cells in the exponential phase were collected by centrifugation at $6000 \mathrm{rpm}$ for $10 \mathrm{~min}$ and the pellet was washed twice with biological saline $(0.85 \% \mathrm{KCl})$. The pellet was 
resuspended in biological saline and the $\mathrm{OD}_{600}$ was adjusted to 1.5. The roots were soaked for $2 \mathrm{~h}$ in the bacterial culture or sterile water (controls) and the seedlings were transplanted into plastic $1500 \mathrm{~cm}^{3}$ pots containing $750 \mathrm{~g}$ of soil (six plants pot ${ }^{-1}$ ). The plant seedlings were allowed to grow in a greenhouse at $25 \pm 5^{\circ} \mathrm{C}$ and a 16:8 $\mathrm{h} \mathrm{d}$ /night regime. Each treatment was performed in five replicates. Plants were watered with deionized water three times per week. After $75 \mathrm{~d}$, the plants were carefully removed from the pots and the root surface was cleaned several times with deionized water. To examine the introduced strains (E4L5, E1S2, E2S2, E4S1 and E1L), tissues (roots, stems and leaves) of $S$. plumbizincicola were ground up with a sterile mortar and pestle in $5 \mathrm{~mL}$ of sterile deionized water. Serial dilutions of plant tissue materials were spread on plates containing SLP agar with $\mathrm{Cd}\left(\mathrm{CdSO}_{4}\right)$ (200 mg L-1), $\mathrm{Zn}\left(\mathrm{ZnSO}_{4}\right)$ (700 mg L-1) and $\mathrm{Pb}\left[\mathrm{Pb}\left(\mathrm{NO}_{3}\right)_{2}\right]\left(1000 \mathrm{mg} \mathrm{L}^{-1}\right)$ according to metal resistance of isolates. After incubation for $7 \mathrm{~d}$ at $28^{\circ} \mathrm{C}$, the reisolated, metal-resistant strains were identified for colony characteristics (morphology and color), metalresistance $(\mathrm{Cd}, \mathrm{Zn}$ and $\mathrm{Pb})$ and $\mathrm{ACC}$ deaminase activity against the parent strains. Plant root and shoot length, fresh and dry weight were measured. The accumulation of elements ( $\mathrm{Cd}, \mathrm{Zn}, \mathrm{Pb}$ and $\mathrm{Fe}$ ) in roots and shoots was quantified by AAS after digestion with perchloric acid, sulfuric acid and distilled water at the ratio of 1:0.75:0.75 (v/v/v) according to the modified sulfuric-perchloric acid digestion method (Fenton and Fenton, 1979 and Ma et al., 2010). The content of phosphorus $(\mathrm{P})$ in tissues of $S$. plumbizincicolawas determined by the molybdenum-ascorbic acid method (Murphy and Riley, 1962) after digestion with $\mathrm{HNO}_{3}$ and $\mathrm{HClO}_{4}(1: 1 \mathrm{v} / \mathrm{v})$.

\subsection{Statistical analysis}

The normality and homogeneity of variances of the data were verified using the Shapiro-Wilk and the Levene test, respectively. The $B$. napus growth data were analyzed using two-way analysis of variance (ANOVA) for each dependent variable (RER of root and shoot, plant fresh and dry weight and vigor index) versus the independent variables [Cd concentration $(\mathrm{Cd})$ and bacterial strain (BS)]. When a significant $F$-value was obtained $(p<0.05)$, treatment means were compared using the Fisher's least significant difference (LSD) test. For the remaining data, treatment means were compared using one-way ANOVA followed by the post-hoc Fisher's LSD test $(p<0.05)$. All the statistical analyses were performed using SPSS 10.0. 


\section{Results and discussion}

\subsection{Isolation, characteristics and identification of metal resistant PGPE}

A total of 42 morphologically different metal-resistant endophytic bacterial strains were isolated and repeatedly screened for their metal resistance in SLP medium supplemented with $100 \mathrm{mg} \mathrm{L}^{-1}$ of $\mathrm{Cd}, \mathrm{Zn}$ or Pb. In order to screen the PGPE, all isolates were qualitatively tested for their ability to grow on DF salts minimal medium with ACC. The results showed that five isolates, designated E1S2, E4S1, E2S2, E4L5 and E1L were able to grow in DF salts minimal medium with ACC as a sole $\mathrm{N}$ source (data not shown). Bacterial strains possessing ACC deaminase are able to reduce ethylene production in stressed plants resulting from a decrease in its precursor ACC, thus enhancing the root elongation and the growth of plants (Belimov et al., 2009). Further, five ACC utilizing isolates were repeatedly screened for their effect on the growth of $B$. napus in Petri dishes with or without $\mathrm{Cd}(6 \mu \mathrm{M} \mathrm{CdCl}$ ). In general, inoculation of ACC utilizing strains recorded a significant increase in RER of root and shoot, fresh and dry weight of $B$. napus (Table 2). However, strain E2S2 showed maximum plant growth promoting activities in both unpolluted and polluted media. For instance, in the presence of Cd, the inoculation of E2S2 enhanced RER of root and shoot by 183 and $209 \%$, respectively; fresh and dry weight of B. napus by 55 and $73 \%$, respectively; and vigor index by $109 \%$ compared to non-inoculated controls.

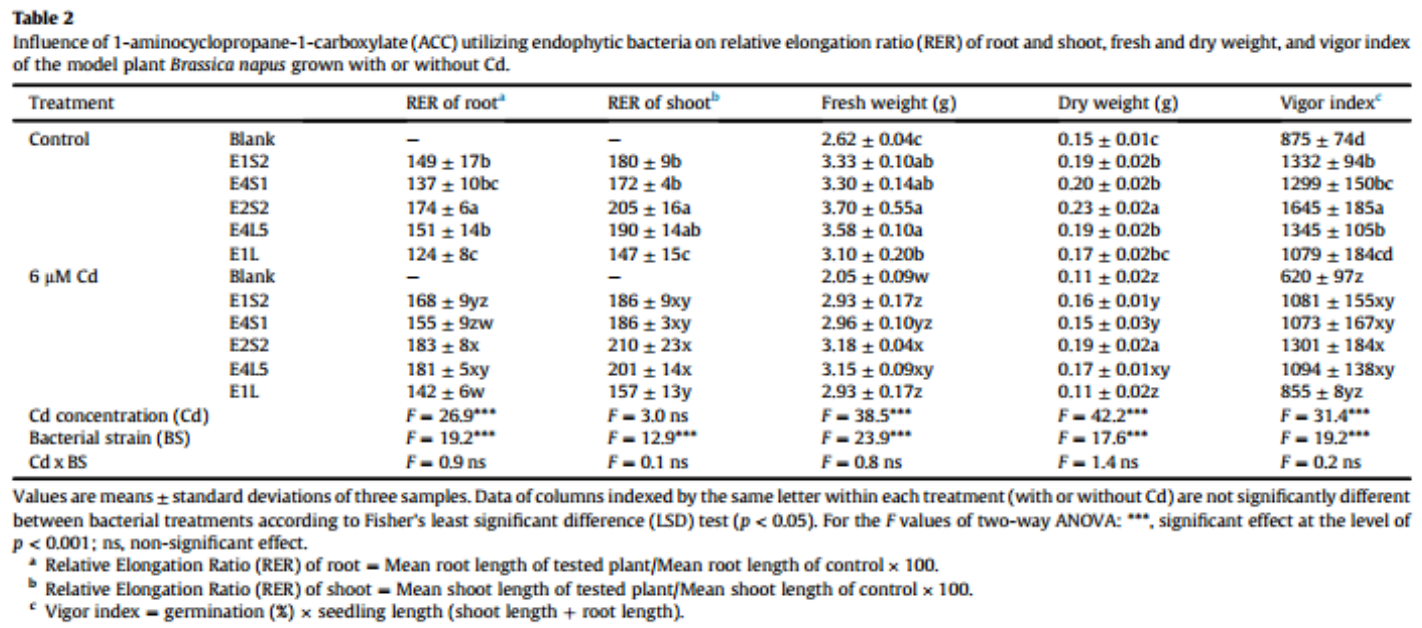

On the basis of morphological, physiological, biochemical characteristics (data not shown) and comparative analysis of the partial 16S rDNA sequence with already available database showed that strains E1S2 (847 bp) and E4S1 (843 bp) were close to the members of the genus Bacillus. Strain E2S2 (841 bp) was identified as Bacillus pumilus and E4L5 (855 bp) showed high similarity with Achromobacter sp., as did E1L (832 bp) with Stenotrophomonas sp. The 
partial 16S rRNA sequences of endophytic bacteria were deposited in the GenBank nucleotide sequence database under the following accession numbers: AY660543 (Achromobacter sp. E4L5), AY660542 (Bacillus sp. E1S2), AY660546 (B. pumilus E2S2), AY660545 (Bacillus sp. E4S1), and AY660547 (Stenotrophomonas sp. E1L).

\subsection{Plant beneficial features of ACC utilizing endophytic bacteria}

Microorganisms isolated from natural contaminated environments often possess tolerance to multiple pollutants and various antibiotics, which possibly help them to adapt to such stressful environments (Pal et al., 2005). In this study, the ACC utilizing strains were found highly resistant to $\mathrm{Cd}, \mathrm{Zn}$ or $\mathrm{Pb}$ when cultivated under increasing metal levels in the growth medium. Extremely high $\mathrm{Cd}$ and $\mathrm{Zn}$ resistance (up to the concentration of $400 \mathrm{mg} \mathrm{L}^{-1}$ and $1500 \mathrm{mg} \mathrm{L}^{-1}$, respectively) was observed for the strain E2S2, whereas strain E1L showed maximum resistance to $\mathrm{Pb}\left(6000 \mathrm{mg} \mathrm{L}^{-1}\right)$ with relatively low resistance to $\mathrm{Cd}$ and $\mathrm{Zn}$. The order of the toxicity of the metals to the strains was found to be $\mathrm{Cd}>\mathrm{Zn}>\mathrm{Pb}$ (Table 3). This high resistance to heavy metals could be attributed to the fact that the ACC utilizing strains were isolated from the tissues of the hyperaccumulatorS. plumbizincicola, which can accumulate $\mathrm{Cd}$ and $\mathrm{Zn}$ from multi-metal contaminated mine soils (Wu et al., 2008) and therefore provide a specific niche to host endophytic bacteria. Besides, out of 5 tested antibiotics, all the ACC utilizing strains exhibited resistance against ampicillin, chloramphenicol, kanamycin and tetracycline (Table 3). It has been reported the antibiotic resistance properties of bacteria are often concomitant with heavy metal tolerance (Rajkumar et al., 2008).

\begin{tabular}{|c|c|c|c|c|c|c|c|c|}
\hline \multirow[t]{3}{*}{ Strain } & \multicolumn{3}{|c|}{ Minimum inhibitory concentrations } & \multicolumn{5}{|c|}{ Antibiotic resistance (diameter of inhibition zone: $\mathrm{mm}$ ) } \\
\hline & $\mathrm{cd}$ & $\mathrm{Zn}$ & $\mathrm{Pb}$ & \multirow{2}{*}{$\frac{\text { Ampicillin }}{20 \mu \mathrm{g}}$} & \multirow{2}{*}{$\frac{\text { Tetracycline }}{30 \mu g}$} & \multirow{2}{*}{$\frac{\text { Streptomycin }}{20 \mu g}$} & \multirow{2}{*}{$\frac{\text { Chloramphenicol }}{30 \mu \mathrm{g}}$} & \multirow{2}{*}{$\frac{\text { Kanamycin }}{30 \mu \mathrm{g}}$} \\
\hline & $\overline{\mathrm{mg} \mathrm{L} \mathrm{L}^{-}}$ & & & & & & & \\
\hline E1S2 & 300 & 750 & 4500 & $1(\mathrm{R})$ & $2(R)$ & $0(R)$ & $0(R)$ & $2(\mathrm{R})$ \\
\hline E4S1 & 300 & 750 & 3500 & $2(\mathrm{R})$ & 1 (R) & $18(S)$ & 0 (R) & $4(\mathrm{R})$ \\
\hline E2S2 & 400 & 1500 & 3500 & 0 (R) & $1(\mathrm{R})$ & 15 (1) & $0(R)$ & $0(\mathrm{R})$ \\
\hline EAL5 & 250 & 1500 & 1000 & 6 (R) & $0(R)$ & $3(R)$ & 0 (R) & 2 (R) \\
\hline E1L & 350 & 750 & 6000 & 0 (R) & $0(R)$ & $0(R)$ & 0 (R) & 0 (R) \\
\hline
\end{tabular}

The metal adaptation capability and metal biomobilization potential of endophytic bacteria can contribute to hamper the detrimental effect of metal pollution, making them promising for microbe-assisted phytoremediation (Ma et al., 2011a). IAA production was observed in all strains (Table 4). Strain E2S2 produced the highest amount, $128.7 \mathrm{mg} \mathrm{L}^{-1}$ of IAA, followed by strain E4S1, which produced $116.2 \mathrm{mg} \mathrm{L}^{-1}$ of IAA. E1S2, E4L5 and E1L produced similar amounts of IAA, i.e., 24.5, 22.8, and $45.3 \mathrm{mg} \mathrm{L}^{-1}$, respectively. It has been well documented that the bacterial IAA contribute much to the 
plant growth and development by regulating cell division and differentiation (Berleth and Sachs, 2001). This is largely supported by our findings. Increases in RER of root and shoot as well as biomass of $B$. napus ( Table 2 ) are clearly correlated to the maximum biosynthesis of IAA by B. pumilus E2S2 ( Table 4). Moreover, all five strains exhibited Psolubilizing ability by utilizing the insoluble TCP as the sole source of $\mathrm{P}$ in modified Pikovskayas medium (Table 4). The decolorization of bromophenol blue is due to a decrease in $\mathrm{pH}$ caused by the excretion of organic or inorganic acids, which is considered to be responsible for $P$ solubilization (Rashid et al., 2004). The strain E4L5 recorded the maximum solubilization of $P$ followed by E1S2. It has been demonstrated that the elevated levels of metals in soil interfere with uptake of nutrients such as $P$ and can lead to plant growth retardation. This deficiency can be compensated by the Psolubilizing ability of PGPE strains (He et al., 2013). Besides, most of the commonly known ACC deaminase and siderophore-producing bacteria can prevent the ethyleneinduced inhibition of root elongation through hydrolytic cleavage of ACC and suppressing the ACC synthase activity (Belimov et al., 2009). In our study, strain E2S2 showed the highest ACC deaminase activity (32.6 $\mu \mathrm{mol} \alpha-\mathrm{KB} \mathrm{mg}^{-1} \mathrm{~h}^{-1}$ protein) (Table 4), by which it exerts the optimum of plant growth promoting traits under both $\mathrm{Cd}$ stress and unstressed condition (Table 2). Further, all five strains also displayed a positive siderophore activity indicated by the formation of orange colored zone on CAS agar plates. Strain E4S1 showed the ability to produce the highest levels of catechol and hydroxamate siderophores by 891.6 and $51.1 \mathrm{mg} \mathrm{L}^{-1}$, respectively (Table 4).

\begin{tabular}{|c|c|c|c|c|c|c|}
\hline \multirow[t]{3}{*}{ Strain } & \multirow{3}{*}{$\begin{array}{l}\text { ACC deaminase } \\
\frac{\mu \mathrm{mol} \alpha-\mathrm{KB} \mathrm{mg}^{-1} \mathrm{~h}^{-1}}{}\end{array}$} & \multirow{3}{*}{$\begin{array}{l}\text { P solubilization } \\
\mathrm{mg} \mathrm{L}^{-1}\end{array}$} & \multirow{3}{*}{$\begin{array}{l}\text { IAA synthesis } \\
\mathrm{mg} \mathrm{L}^{-1}\end{array}$} & \multicolumn{3}{|c|}{ Siderophore production } \\
\hline & & & & \multirow{2}{*}{$\frac{\text { CAS assay }}{\mathrm{cm}}$} & \multirow{2}{*}{$\frac{\text { Catechol }}{\mathrm{mg} \mathrm{L} \text { L }^{-1}}$} & \multirow{2}{*}{$\frac{\text { Hydroxamate }}{\mathrm{mg} \mathrm{L}^{-1}}$} \\
\hline & & & & & & \\
\hline E1S2 & $23.5 \pm 2.5 \mathrm{~b}$ & $151.6 \pm 7.4 b$ & $24.5 \pm 1.2 \mathrm{~d}$ & $1.1 \pm 0.3 \mathrm{~b}$ & $219.1 \pm 13.8 c$ & $21.3 \pm 1.3 \mathrm{bc}$ \\
\hline E4S1 & $14.0 \pm 2.1 \mathrm{c}$ & $53.6 \pm 2.4 e$ & $116.2 \pm 2.4 \mathrm{~b}$ & $1.9 \pm 0.1 \mathrm{a}$ & $891.6 \pm 25.2 \mathrm{a}$ & $51.1 \pm 0.4 \mathrm{a}$ \\
\hline E2S2 & $32.6 \pm 4.8 \mathrm{a}$ & $64.1 \pm 4.3 \mathrm{~d}$ & $128.7 \pm 14.2 \mathrm{a}$ & $1.5 \pm 0.3 \mathrm{ab}$ & $420.8 \pm 16.4 b$ & $26.3 \pm 1.4 \mathrm{~b}$ \\
\hline EALS & $14.8 \pm 2.6 c$ & $166.7 \pm 3.7 \mathrm{a}$ & $22.8 \pm 0.5 \mathrm{~d}$ & $1.0 \pm 0.2 b$ & $216.6 \pm 1.5 c$ & $20.1 \pm 0.3 c$ \\
\hline E1L & $11.5 \pm 1.0 \mathrm{c}$ & $126.9 \pm 9.8 c$ & $45.3 \pm 2.6 c$ & $1.1 \pm 0.2 \mathrm{~b}$ & $215.8 \pm 7.5 c$ & $20.7 \pm 0.2 \mathrm{bc}$ \\
\hline
\end{tabular}

\subsection{Effect of PGPE on heavy metal mobility}

In general, significant increase $(p<0.05)$ in water-soluble $\mathrm{Cd}$ and $\mathrm{Zn}$ from the metal contaminated soils by the five strains was observed compared to the control treatments. This was associated with a pH decrease (Fig. 1 a and b). The maximum concentrations were typically observed for $\mathrm{Cd}$ (Fig. 1 a). Inoculation of E2S2 significantly increased the concentrations of water extractable $\mathrm{Cd}, \mathrm{Zn}$ and $\mathrm{Pb}$ in soil by 13.3-, 4.6- and 1.2-folds, respectively relative to the control treatment. The increased soil metal mobility can probably be attributed to acidification and siderophore production by strain E2S2, which facilitated metal solubility in multi-metal contaminated soils. Siderophore production has been proved to be stimulated by the presence of heavy metals (Gaonkar and Bhosle, 2013), and most of them, either catechols or hydroxamates, show strong affinity to divalent metal ions (Ma et al., 2009). Consequently they can possibly affect heavy metal bioavailability in soils as well. For instance, it was reported that metal-resistantPsychrobacter sp. SRA1 and Bacillus cereus SRA10 increased 
the amount of $\mathrm{Ni}$ extracted from soil, which may be due to their ability to produce maximum siderophores both in catechol and hydroxamate types (Ma et al., 2009). Besides, He et al. (2013) reported that the addition of the metal-resistant endophyte Rahnella sp. JN6 to metal contaminated soils significantly increased the water soluble $\mathrm{Cd}, \mathrm{Pb}$ and $\mathrm{Zn}$ by $4.73,6.21$ and 7.19 folds compared with the control, respectively. 


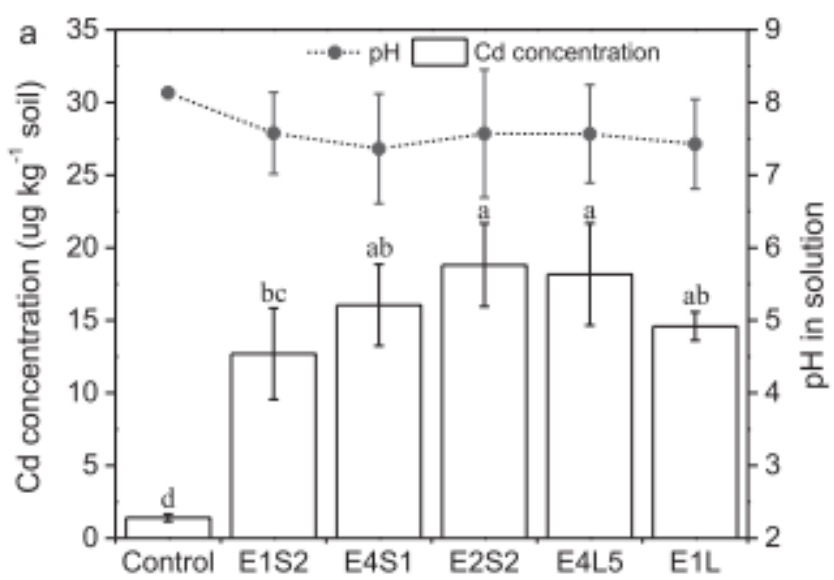

Endophytic bacterial strain

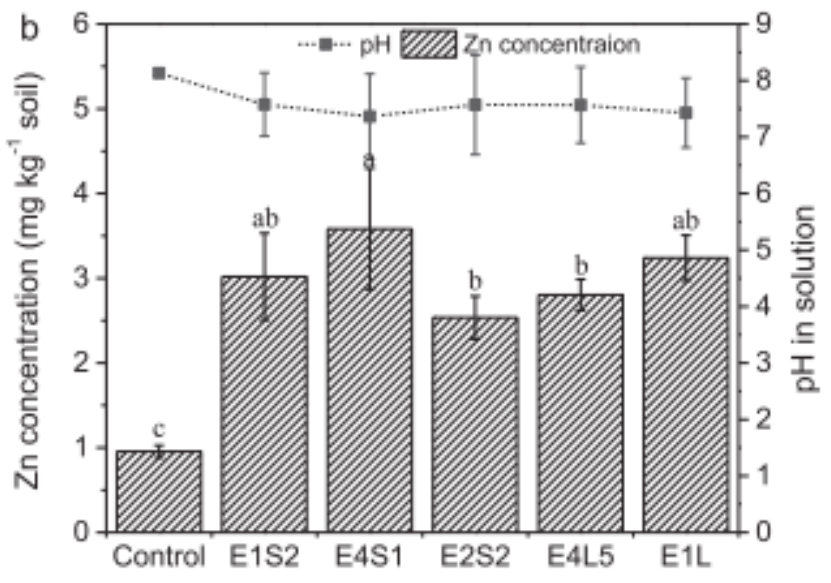

Endophytic bacterial strain

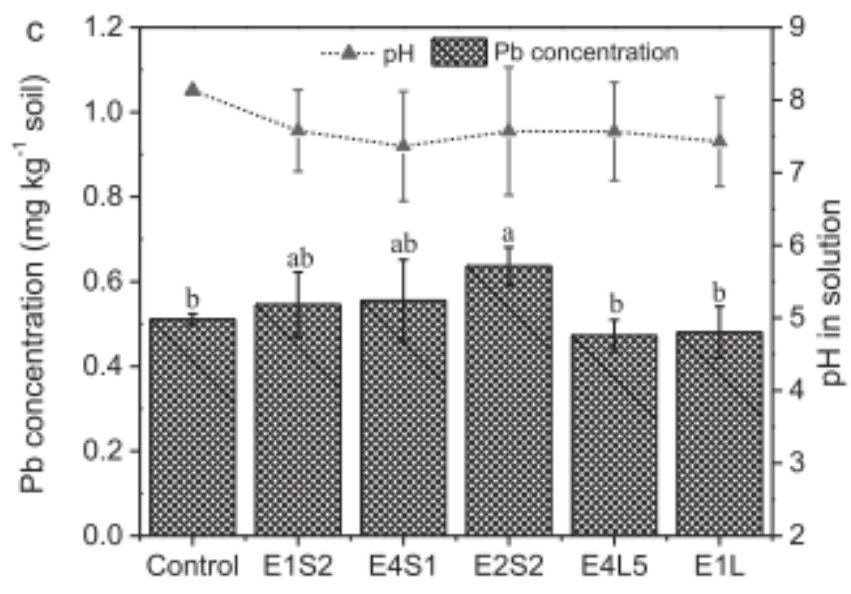

Endophytic bacterial strain

Fig. 1. Effect of inoculation with endophytic bacteria on the mobilization of $\mathrm{Cd}$ (a), Zn (b) and $\mathrm{Pb}$ (c) in soil and on the pH of the metal extract solution. Each value of concentration and $\mathrm{pH}$ is the mean of three replicates. Error bars represent standard deviation. Data of columns indexed by the same letter are not significantly different according to Fisher's least significant difference (LSD) test $(p<0.05)$. 


\subsection{Effect of PGPE on plant growth and heavy metal uptake}

As indicated in Table 1, the concentrations of $\mathrm{Cd}$ and $\mathrm{Zn}$ were very high in the metal contaminated soil used in metal mobilization and pot experiments. The concentration of total $\mathrm{Cd}$ and $\mathrm{Zn}$ were up to $5.9 \mathrm{mg} \mathrm{kg}^{-1}$ and $736 \mathrm{mg} \mathrm{kg}^{-1}$, respectively, which are much higher than the limits of the national second-class standard (0.3 mg Cd kg-1 and $\left.250 \mathrm{mg} \mathrm{Zn} \mathrm{kg}^{-1}\right)$ in the People's Republic of China environmental quality standard for soils (NSPRC, 1995). Inoculated and noninoculated control plants were subjected to the metal contaminated soil (Table 1) for $75 \mathrm{~d}$ and showed significant growth differences (Table 5). S. plumbizincicola inoculated with ACC utilizing strains exhibited significant growth increases. The highest plant growth promoting effect was found for strain E2S2, which enhanced root and shoot length, plant fresh and dry weight by $146,17,37$ and $32 \%$, respectively. The increase in plant growth caused by the PGPE strains under non-sterile conditions may be attributed to their ability to produce ACC deaminase, IAA, siderophores and P solubilization activity (Ma et al., 2011b and $\mathrm{He}$ et al., 2013). The results obtained here clearly indicate that inoculation with strain E2S2 was highly efficient at protecting S. plumbizincicola from growth inhibition caused by toxic metal concentrations in soil, although S. plumbizincicola has great potential to tolerate high metal concentrations and grow in metal contaminated soil. This result is in agreement with a previous report describing increased biomass production of $B$. napus inoculated with ACC utilizing strains (e.g., Ralstonia sp. J1-22-2, Pantoea agglomerans Jp3-3, andPseudomonas thivervalensis Y1-3-9) grown in $\mathrm{Cu}-$ contaminated substrates (Zhang et al., 2011).

\begin{tabular}{|c|c|c|c|c|}
\hline \multirow[t]{2}{*}{ Treatment } & Root length & Shoot length & Fresh weight & Dry weight \\
\hline & $\mathrm{cm}$ & $\mathrm{cm}$ & $\mathrm{g} \mathrm{plant}^{-1}$ & g plant ${ }^{-1}$ \\
\hline $\begin{array}{l}\text { Control } \\
\text { E1S2 }\end{array}$ & $\begin{array}{l}4.6 \pm 0.3 c \\
8.7 \pm 1.3 b\end{array}$ & $\begin{array}{l}17.2 \pm 1.2 c \\
20.6 \pm 0.9 b\end{array}$ & $\begin{array}{l}44.2 \pm 1.1 c \\
58.4 \pm 4.4 a b\end{array}$ & $\begin{array}{l}4.4 \pm 0.1 c \\
5.5 \pm 0.6 a\end{array}$ \\
\hline E4S1 & $9.1 \pm 1.0 \mathrm{~b}$ & $20.2 \pm 0.4 b c$ & $54.9 \pm 2.8 b$ & $4.9 \pm 0.2 b$ \\
\hline E2S2 & $11.3 \pm 1.9 \mathrm{a}$ & $20.1 \pm 2.2 b c$ & $60.4 \pm 2.2 \mathrm{a}$ & $5.8 \pm 0.5 a$ \\
\hline E4L.5 & $8.7 \pm 1.7 b$ & $23.0 \pm 3.3 \mathrm{a}$ & $59.7 \pm 4.5 \mathrm{ab}$ & $5.6 \pm 0.5 a$ \\
\hline E1L. & $9.5 \pm 1.1 b$ & $19.7 \pm 1.0 \mathrm{bc}$ & $59.0 \pm 3.4 a b$ & $5.5 \pm 0.3 a$ \\
\hline
\end{tabular}

Values are means \pm standard deviations of five samples. Data of columns indexed by the same letter are not significantly different between bacterial treatments according to Fisher's least significant difference (LSD) test $(p<0.05)$.

Since the process of phytoextraction by different plants depends on both plant biomass yield and metal uptake/accumulation capacity (Ma et al., 2011a), we also assessed whether inoculation of $S$. plumbizincicola plants with beneficial endophytic bacteria affected the uptake of metals (Cd, Zn and Pb) (Fig. 2). In general, the total uptake of Cd and $\mathrm{Zn}$ by $S$. plumbizincicola plants was significantly increased by the ACC utilizing endophytic bacterial strain E1S2, E4S1, E2S2 and E1L, compared to non-inoculated 
controls (Fig. 2). The inoculation of the best Cd mobilizer E2S2 significantly increased the accumulation of $\mathrm{Cd}$ in S. plumbizincicola by $43 \%$ compared with non-inoculated controls. Similarly, the maximum increase (18\%) in accumulation of $\mathrm{Zn}$ in plants was observed when plants were inoculated with strain E1S2. The increased metal uptake induced by endophytic bacteria can be attributed to their capability of solubilizing metals in the rhizosphere of the inoculated plants through bacterial metabolic activities or their interactions with host plants (He et al., 2013). The acidification (lowering of soil pH) of surroundings resulting from $\mathrm{P}$ solubilization may play a key role on the solubility and accumulation of heavy metals (Rajkumar et al., 2009 and Ma et al., 2011a). Several observations have evidenced that metal-resistant endophytic bacteria can alter the metal uptake capacity of hyperaccumulator plants (Visioli et al., 2014 and Zhu et al., 2014). However, bacterial inoculation did not significantly influence $\mathrm{Pb}$ accumulation in plants $(p>0.05)$. This observation indicates that other mechanisms, e.g. a direct dilution of metal concentrations by increased plant biomass rather than bacterial metal mobilization were involved. The application of the metal-resistant ACC utilizing endophytic bacteria not only effectively promoted the plant growth, but also increased the bioavailability of metals in the rhizosphere and consequently enhanced the uptake of $\mathrm{Cd}$ and $\mathrm{Zn}$ byS. plumbizincicola. Although PGPE have been used as bioinoculants in phytoremediation scenarios, most of the studies on their effects on plant growth and metal uptake have only been performed in sterile metal polluted soils or growth media (Ma et al., 2011a, He et al., 2013, Visioli et al., 2014 and Zhu et al., 2014).

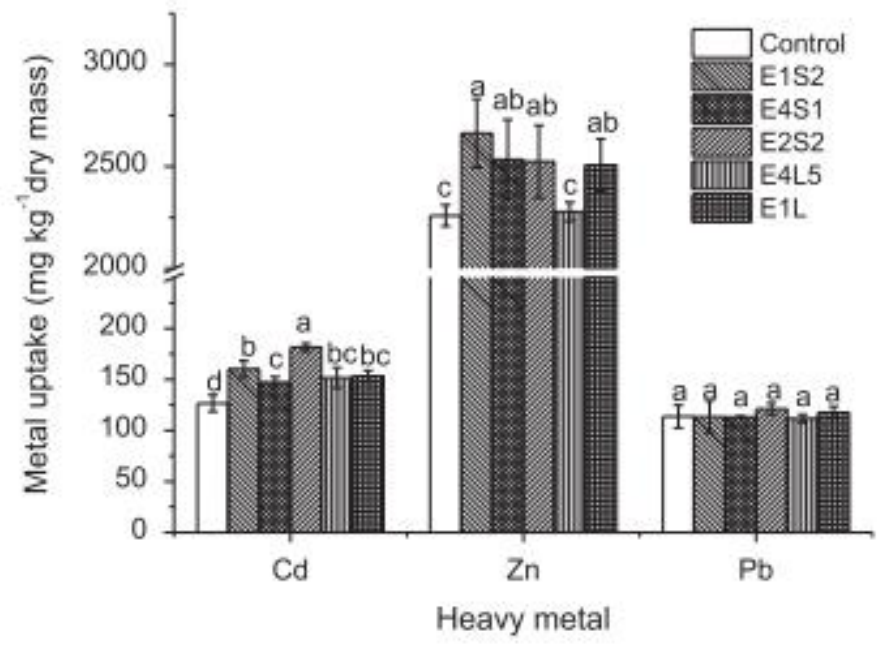

Fig. 2 Influence of endophytic bacteria on the metal concentration in Sedum plumbizincicola grown in metal contaminated soil. Each value is the mean of triplicates Error bars represent standard deviation. Data of columns indexed by the same letter are not significantly different according to Fisher's least significant difference (LSD) test $(p<0.05)$.

Soils contaminated with heavy metals often present other plants stresses, such as nutrient (e.g. Fe, P, Mg and Ca) deficiency (Ma et al., 2010 and Wan et al., 2012). It has been well documented that PGPE help plants to acquire Fe and $P$ though the activities of siderophore production and $\mathrm{P}$ solubilization, which can be important contributions to the beneficial effect of bacteria on plant establishment and subsequent growth in metal contaminated sites (Ma et al., 2011a and Ma et al., 2011b). In our study, inoculation of all of the ACC utilizing strains did not significantly change the Fe contents in tissues of $S$. plumbizincicola, while significant increases in $\mathrm{P}$ contents in plant shoots were detected after bacterial inoculation, when compared with control treatments $(p<0.05)$ (Table 6). Dissimilarly, several previous studies reported increase in uptake of nutrients 
(Fe or $\mathrm{P}$ ) by plants as a result of inoculations of siderophore producing or $\mathrm{P}$-solubilizing bacteria (Biari et al., 2008 and Ma et al., 2010).

Table 6

Influence of 1-aminocyclopropane-1-carboxylate (ACC) utilizing strains on Fe and P content in Sedum plumbizincicola.

\begin{tabular}{|c|c|c|c|c|}
\hline \multirow[t]{2}{*}{ Treatment } & \multicolumn{2}{|c|}{ Fe content (mg kg ${ }^{-1}$ dry mass) } & \multicolumn{2}{|c|}{ P content ( $\mathrm{mg} \mathrm{kg}{ }^{-1}$ dry mass) } \\
\hline & Shoots & Roots & Shoots & Roots \\
\hline $\begin{array}{l}\text { Control } \\
\text { E1S2 }\end{array}$ & $\begin{array}{l}500.3 \pm 82.3 \mathrm{a} \\
472.7 \pm 20.2 \mathrm{a}\end{array}$ & $\begin{array}{l}6045.0 \pm 890.9 a b \\
5698.7 \pm 342.0 b c\end{array}$ & $\begin{array}{r}77.8 \pm 4.3 c \\
102.8 \pm 3.6 a\end{array}$ & $\begin{array}{l}129.4 \pm 20.5 \mathrm{ab} \\
177.2 \pm 5.5 \mathrm{a}\end{array}$ \\
\hline E4S1 & $566.5 \pm 50.4 a$ & $4925.8 \pm 407.7 c$ & $102.6 \pm 7.7 a$ & $57.9 \pm 2.4 b$ \\
\hline E2S2 & $522.3 \pm 87.7 a$ & $6129.2 \pm 451.4 a b$ & $89.9 \pm 12.0 b$ & $202.8 \pm 28.2 \mathrm{a}$ \\
\hline EALS & $548.3 \pm 65.9 \mathrm{a}$ & $6890.9 \pm 65.9 a$ & $101.4 \pm 5.1 \mathrm{a}$ & $145.5 \pm 8.4 a$ \\
\hline E1L. & $515.1 \pm 67.5 a$ & $5878.0 \pm 610.1 b$ & $103.8 \pm 8.4 a$ & $169.4 \pm 33.9 \mathrm{a}$ \\
\hline
\end{tabular}

Although the inoculated ACC utilizing endophytic strains possess several traits which facilitate the plant growth and metal uptake, as successful plant beneficial inoculants, bacteria must be able to rapidly colonize the root system and survival in metal stress environment during the growing season (Rajkumar et al., 2009). In the present study, the five metal-resistant ACC utilizing endophytic bacteria tested were able to colonize the rhizosphere or plant tissue interiors of $S$. plumbizincicola. The numbers of the bacterial colonies in the rhizosphere and tissues of $S$. plumbizincicola plants were $10^{4}$ $10^{5} \mathrm{CFU} \mathrm{g^{-1 }}$ of fresh rhizospheric soil, $10^{3} \mathrm{CFU} \mathrm{g^{-1 }}$ of fresh root and stems, and $10^{2} \mathrm{CFU} \mathrm{g}^{-1}$ of fresh leaves (Table 7). Strain E2S2 showed higher level of colonization in tissue (leaf, stem and root) interior and rhizosphere of $S$. plumbizincicola, compared to the other endophytic strain inoculation treatments. In addition, the production of plant cell wall degrading enzymes by endophytes such as cellulase and pectinase was determined, since these extracellular enzymes may confer an advantage of intercellular ingress and facilitate vertical spreading of endophytes into the host plants, which has been considered as an important mechanism for endophytic colonization (Verma et al., 2001). Among the five strains tested, E2S2 exerted a positive cellulase activity by the development of yellow-colored zone on NFB plates. However, except for strain E1L, the other four strains exhibited positive pectinase activity. Ma et al. (2011b) recently reported that the production of bacterial cellulase and pectinase enzymes facilitated colonization of endophyte Pseudomonas sp. A3R3 in tissues of both host plant Alyssum serpyllifoliumand non-host plant Brasscia juncea and suggested that production of extracellular enzymes by endophytes plays an important role in plant-microbe interactions and intercellular colonization of plant tissues.

Table 7

Colonization of 1-aminocyclopropane-1-carboxylate (ACC) utilizing strains in the rhizosphere soil and tissue interior of Sedum plumbizincicola after inoculation with seedlings grown in metal contaminated soil.

\begin{tabular}{lclll}
\hline Treatment & Rhizosphere & Root interior & Stem interior & Leaf interior \\
\hline E1S2 & $102.3 \pm 6.8 \mathrm{bc}$ & $3.2 \pm 0.4 \mathrm{c}$ & $1.0 \pm 0.4 \mathrm{~b}$ & $0.4 \pm 0.1 \mathrm{~b}$ \\
E4S1 & $89.7 \pm 8.5 \mathrm{c}$ & $2.9 \pm 0.2 \mathrm{~cd}$ & $1.3 \pm 0.3 \mathrm{ab}$ & $0.4 \pm 0.0 \mathrm{~b}$ \\
E2S2 & $143.3 \pm 13.0 \mathrm{a}$ & $4.4 \pm 0.3 \mathrm{a}$ & $1.7 \pm 0.2 \mathrm{a}$ & $0.6 \pm 0.0 \mathrm{a}$ \\
E4L5 & $112.0 \pm 12.1 \mathrm{~b}$ & $3.8 \pm 0.1 \mathrm{~b}$ & $1.3 \pm 0.4 \mathrm{ab}$ & $0.4 \pm 0.1 \mathrm{~b}$ \\
E1L & $63.7 \pm 7.4 \mathrm{~d}$ & $2.7 \pm 0.3 \mathrm{~d}$ & $1.1 \pm 0.2 \mathrm{~b}$ & $0.3 \pm 0.1 \mathrm{c}$ \\
\hline
\end{tabular}

Values are means \pm standard deviations of five samples. Data of columns indexed by the same letter are not significantly different between bacterial treatments according to Fisher's least significant difference (LSD) test $(p<0.05)$. Values in $10^{3} \mathrm{CFU} \mathrm{g}^{-1}$ of fresh soil or plant tissue. 


\section{Conclusions}

Our research demonstrated that metal-resistant ACC utilizing endophytic bacteria isolated from the tissues of $S$. plumbizincicola plants grown in a metal contaminated mine soil, are able to adapt and survive at high concentration of metals and possess various plant beneficial features including production of plant growth promoting substances such as IAA, siderophore and ACC deaminase or/and solubilization of $P$, as well as production of extracellular enzymes such as pectinase and cellulase. Further, our results showed that inoculation of ACC utilizing strains, especially $B$. pumilus E2S2 significantly increased mobilization of $\mathrm{Cd}$ and $\mathrm{Zn}$ in soil and subsequent uptake of these metals in the tissues of $S$. plumbizincicola, together with concurrent stimulation of plant growth. Further investigations on the efficiency of this ACC utilizing endophytic bacterial strain as a bioinoculant for improving the phytoextraction of multi-metal polluted soils under field conditions are in progress.

\section{References}

1.

- Altschul et al., 1997

- S.F. Altschul, T.L. Madden, A.A. Schaffer, J. Zhang, Z. Zhang, W. Miller, D.J. Lipman

- Gapped BLAST and PSI-BLAST: a new generation of protein database search programs

○ Nucleic Acids Res., 25 (1997), pp. 3389-3402

2.

○ Arnow, 1937

- E. Arnow

○ Colorimetric determination of the components of 3,4-dihydroxyphenylalaninetyrosine mixtures

○ J. Biol. Chem., 118 (1937), pp. 531-537

3.

○ Atkin et al., 1970

$\circ \quad$ C.L. Atkin, J.B. Neilands, H.J. Phaff

○ Rhodotorulic acid of Leucosporidium, Rhodosporidium, Rhodotorula,Sporidiobolus, and Sporobolomyces, and a new alanine-containing ferrichrome from Cryptococcus melibiosum

○ J. Bacteriol., 103 (1970), pp. 722-733 
4.

- Biari et al., 2008

- A. Biari, A. Gholami, H.A. Rahmani

$\circ$ Growth promotion and enhanced nutrient uptake of maize (Zea mays L.) by application of plant growth promoting rhizobacteria in arid region of Iran

○ J. Biol. Sci., 8 (2008), pp. 1015-1020

5.

- Belimov et al., 2009

- A.A. Belimov, I.C. Dodd, N. Hontzeas, J.C. Theobald, V.I. Safronova, W.J. Davies

$\circ$ Rhizosphere bacteria containing 1-aminocyclopropane-1-carboxylate deaminase increase yield of plants grown in drying soil via both local and systemic hormone signalling

○ New. Phytol., 181 (2009), pp. 413-423

6.

- Berleth and Sachs, 2001

- T. Berleth, T. Sachs

- Plant morphogenesis: long distance coordination and local patterning

- Curr. Opin. Plant Biol., 4 (2001), pp. 57-62

7.

- Branco et al., 2005

$\circ \quad$ R. Branco, A.P. Chung, A. Verıssimo, P.V. Morais

- Impact of chromium contaminated wastewaters on the microbial community of a river

- FEMS Microbiol. Ecol., 54 (2005), pp. 35-46

8.

- Bric et al., 1991

- J.M. Bric, R.M. Bostock, S.E. Silversone

- Rapid in situ assay for indole acetic acid production by bacteria immobilization on a nitrocellulose membrane

○ Appl. Environ. Microbiol., 57 (1991), pp. 535-538

9.

$\circ \quad$ Dworkin and Foster, 1958

- M. Dworkin, J. Foster

$\circ$ Experiments with some microorganisms which utilize ethane and hydrogen

- J. Bacteriol., 75 (1958), pp. 592-601 
10.

- Fenton and Fenton, 1979

- T.W. Fenton, M. Fenton

$\circ \quad$ An improved procedure for the determination of chromic oxide in feed and feces

- Can. J. Anim. Sci., 59 (1979), pp. 631-634

11.

- Fiske and Subbarow, 1925

○ C.H. Fiske, Y. Subbarow

- A colorimetric determination of phosphorus

○ J. Biol. Chem., 66 (1925), pp. 375-400

12.

○ Freitas et al., 2004

- H. Freitas, M.N.V. Prasad, J. Pratas

- Analysis of serpentinophytes from northeast of Portugal for trace metal accumulation relevance to the management of mine environment

○ Chemosphere, 54 (2004), pp. 1625-1642

13.

- Gaonkar and Bhosle, 2013

- T. Gaonkar, S. Bhosle

- Effect of metals on a siderophore producing bacterial isolate and its implications on microbial assisted bioremediation of metal contaminated soils

○ Chemosphere, 93 (2013), pp. 1835-1843

14.

- Gordon and Weber, 1951

- S.A. Gordon, R.P. Weber

- Colorimetric estimation of indoleacetic acid

○ Plant Physiol., 26 (1951), pp. 192-195

15.

○ He et al., 2013

- H.D. He, Z.H. Ye, D.J. Yang, J.L. Yan, L. Xiao, T. Zhong, M. Yuan, X.D. Cai, Z.Q. Fang, Y.X. Jing

- Characterization of endophytic Rahnella sp. JN6 from Polygonum pubescens and its potential in promoting growth and $\mathrm{Cd}, \mathrm{Pb}, \mathrm{Zn}$ uptake by Brassica napus

- Chemosphere, 90 (2013), pp. 1960-1965

16. 
- Honma and Shimomura, 1978

- M. Honma, T. Shimomura

- Metabolism of 1-aminocyclopropane-1-carboxylic acid

○ Agric. Biol. Chem., 42 (1978), pp. 1825-1831

17.

○ Kane et al., 1993

- M.D. Kane, L.K. Poulsen, D.A. Stahl

○ Monitoring the enrichment and isolation of sulfate-reducing bacteria by using oligonucleotide hybridization probes designed from environmentally derived 16S rRNA sequences

○ Appl. Environ. Microbiol., 59 (1993), pp. 682-686

18.

○ Lane, 1991

○ D.J. Lane

- E. Stackebrandt, M. Goodfellow (Eds.), 16S/23S rRNA Sequencing in Nucleic Acid Techniques in Bacterial Systematics, Wiley, New York (1991), pp. 115-175

19.

○ Lowry et al., 1951

○ O.H. Lowry, N.J. Rosebrough, A.L. Farr, R.J. Randall

- Protein measurement with the folin phenol reagent

○ J. Biol. Chem., 193 (1951), pp. 265-275

20.

○ Ma et al., 2009

○ Y. Ma, M. Rajkumar, H. Freitas

- Improvement of plant growth and nickel uptake by nickel resistant-plant growth promoting bacteria

○ J. Hazard. Mater., 166 (2009), pp. 1154-1161

21.

○ Ma et al., 2010

○ Y. Ma, M. Rajkumar, J. Vicente, H. Freitas

- Inoculation of Ni-resistant plant growth promoting bacterium Psychrobacter sp. strain SRS8 for the improvement of nickel phytoextraction by energy crops

○ Int. J. Phytoremediation, 13 (2010), pp. 126-139

- Full Text via CrossRef 
- Ma et al., 2011a

○ Y. Ma, M.N.V. Prasad, M. Rajkumar, H. Freitas

- Plant growth promoting rhizobacteria and endophytes accelerate phytoremediation of metalliferous soils

○ Biotechnol. Adv., 29 (2011), pp. 248-258

23.

○ Ma et al., 2011b

○ Y. Ma, M. Rajkumar, Y.M. Luo, H. Freitas

- Inoculation of endophytic bacteria on host and non-host plants - effects on plant growth and Ni uptake

○ J. Hazard. Mater., 196 (2011), pp. 230-237

24.

○ Ma et al., 2013

○ Y. Ma, M. Rajkumar, Y. Luo, H. Freitas

- Phytoextraction of heavy metal polluted soils using Sedum plumbizincicola inoculated with metal mobilizing Phyllobacterium myrsinacearum RC6b

○ Chemosphere, 93 (2013), pp. 1386-1392

25.

- Mateos et al., 1992

- P.F. Mateos, J.I. Jimenez-Zurdo, J. Chen, A.S. Squartini, S.K. Haack, E. Martinez-Molina, D.H. Hubbell, F.B. Dazzo

○ Cell-associated pectinolytic and cellulolytic enzymes in Rhizobium leguminosarum bv. Trifolii

○ Appl. Environ. Microbiol., 58 (1992), pp. 1816-1822

26.

- McGrath et al., 2006

- S.P. McGrath, E. Lombi, C.W. Gray, N. Caille, S.J. Dunham, F.J. Zhao

$\circ$ Field evaluation of $\mathrm{Cd}$ and $\mathrm{Zn}$ phytoextraction potential by the hyperaccumulators Thlaspi caerulescens and Arabidopsis halleri

○ Environ. Pollut., 141 (2006), pp. 115-125

27.

○ Murphy and Riley, 1962

- J. Murphy, J.P. Riley

- A modified single solution method for the determination of phosphorus in natural waters 
○ Anal. Chim. Acta, 12 (1962), pp. 31-36

28.

○ NSPRC, 1995

- NSPRC (National Standards of the People's Republic of China)

○ Standards for Soil Environmental Quality: GB15618-1995

○ (1995)

29.

- Pal et al., 2005

- A. Pal, S. Dutta, P.K. Mukherjee, A.K. Paul

Occurrence of heavy metal-resistance in microflora from serpentine soil of Andaman

○ J. Basic Microbiol., 45 (2005), pp. 207-218

30 .

- Rajkumar et al., 2008

- M. Rajkumar, Y. Ma, H. Freitas

- Characterization of metal-resistant plant-growth promoting Bacillus weihenstephanensisisolated from serpentine soil in Portugal

○ J. Basic Microbiol., 48 (2008), pp. 1-9

31.

○ Rajkumar et al., 2009

○ M. Rajkumar, N. Ae, H. Freitas

- Endophytic bacteria and their potential to enhance heavy metal phytoextraction

○ Chemosphere, 77 (2009), pp. 153-160

32.

○ Rajkumar et al., 2013

- M. Rajkumar, Y. Ma, H. Freitas

- Improvement of $\mathrm{Ni}$ phytostabilization by inoculation of $\mathrm{Ni}$ resistant Bacillus megaterium SR28C

○ J. Environ. Manag., 128 (2013), pp. 973-980

33.

- Rashid et al., 2004

- M. Rashid, S. Khalil, N. Ayub, S. Alam, F. Latif

- Organic acids production and phosphate solubilization by phosphate solubilizing microorganisms (PSM) under in vitro conditions

○ Pak. J. Biol. Sci., 7 (2004), pp. 187-196 
34.

- Reeves and Baker, 2000

- R.D. Reeves, A.J.M. Baker

○ Metal-accumulating plants

- I. Raskin, B.D. Ensley (Eds.), Phytoremediation of Toxic Metals: Using Plants to Clean up the Environment, Wiley, New York (2000), pp. 193-229

35.

- Schwyn and Neilands, 1987

- B. Schwyn, J.B. Neilands

$\circ$ Universal chemical assay for the detection and determination of siderophores

- Anal. Biochem., 160 (1987), pp. 47-56

36.

- Sundara-Rao and Sinha, 1963

- W.V.B. Sundara-Rao, M.K. Sinha

$\circ$ Phosphate dissolving microorganisms in the soil and rhizosphere

○ Indian J. Agr. Sci., 33 (1963), pp. 272-278

37.

- Verma et al., 2001

- S.C. Verma, J.K. Ladha, A.K. Tripathi

$\circ$ Evaluation of plant growth promoting and colonization ability of endophytic diazotrophs from deep water rice

○ J. Biotechnol., 91 (2001), pp. 127-141

38.

○ Visioli et al., 2014

- G. Visioli, S. D'Egidio, T. Vamerali, M. Mattarozzi, A.M. Sanangelantoni

- Culturable endophytic bacteria enhance $\mathrm{Ni}$ translocation in the hyperaccumulator Noccaea caerulescens

- Chemosphere, 117 (2014), pp. 538-544

39.

○ Wan et al., 2012

- Y. Wan, S.L. Luo, J.L. Chen, X. Xiao, L. Chen, G.M. Zeng, C.B. Liu, Y.J. He

- Effect of endophyte-infection on growth parameters and $\mathrm{Cd}$-induced phytotoxicity of Cd-hyperaccumulator Solanum nigrum $\mathrm{L}$.

- Chemosphere, 89 (2012), pp. 743-750

40. 
- Wu et al., 2008

○ L.H. Wu, N. Li, Y.M. Luo

- Phytoextraction of heavy metal contaminated soil by Sedum plumbizincicola under different agronomic strategies

○ Proc 5th Int Phytotech Conf, Nanjing, China (2008), pp. 49-50

41.

- Yilmaz, 2003

- E.I. Yilmaz

- Metal tolerance and biosorption capacity of Bacillus circulans strain EB1

- Microbiology, 154 (2003), pp. 409-415

42.

- Zhang et al., 2011

○ Y.F. Zhang, L.Y. He, Z.J. Chen, Q.Y. Wang, M. Qian, X.F. Sheng

- Characterization of ACC deaminase-producing endophytic bacteria isolated from copper-tolerant plants and their potential in promoting the growth and copper accumulation of Brassica napus

- Chemosphere, 1 (2011), pp. 57-62

43.

○ Zhu et al., 2014

○ L.J. Zhu, D.X. Guan, J. Luo, B. Rathinasabapathi, L.Q. Ma

- Characterization of arsenic-resistant endophytic bacteria from hyperaccumulators Pteris vittataand Pteris multifida

○ Chemosphere, 113 (2014), pp. 9-16 